\title{
SÃO TOMÉ E PRÍNCIPE
}

\author{
Area: 964 sq. km \\ Population: 100,000 \\ Capital: São Tomé
}

Head of State: Dr Manuel Pinto da Costa (President, Prime Minister and Minister of National Security and Defence)

São Tomé e Príncipe maintains a small Public Order Police (Policia da Ordem Publica), controlled by the Ministry of National Security, with an estimated personnel strength of 250. The paramilitary National Guard (Guarda Nacional) has 160 men allocated to internal security and rural policing duties. 